\title{
QUEEN'S
UNIVERSITY
BELFAST
}

\section{A statistical analysis of person-to-vehicle communications channels in an urban environment at $5.8 \mathrm{GHz}$}

Doone, M. G., \& Cotton, S. L. (2014). A statistical analysis of person-to-vehicle communications channels in an urban environment at $5.8 \mathrm{GHz}$. In Proceedings of the 2014 USNC-URSI Radio Science Meeting (Joint with AP-S Symposium) (pp. 236). Institute of Electrical and Electronics Engineers Inc.. https://doi.org/10.1109/USNCURSI.2014.6955619

Published in:

Proceedings of the 2014 USNC-URSI Radio Science Meeting (Joint with AP-S Symposium)

Document Version:

Peer reviewed version

Queen's University Belfast - Research Portal:

Link to publication record in Queen's University Belfast Research Portal

Publisher rights

( $) 2015$ IEEE. Personal use of this material is permitted. Permission from IEEE must be obtained for all other uses, in any current or future media, including reprinting/republishing this material for advertising or promotional purposes, creating new collective works, for resale or redistribution to servers or lists, or reuse of any copyrighted component of this work in other works.

\section{General rights}

Copyright for the publications made accessible via the Queen's University Belfast Research Portal is retained by the author(s) and / or other copyright owners and it is a condition of accessing these publications that users recognise and abide by the legal requirements associated with these rights.

Take down policy

The Research Portal is Queen's institutional repository that provides access to Queen's research output. Every effort has been made to ensure that content in the Research Portal does not infringe any person's rights, or applicable UK laws. If you discover content in the Research Portal that you believe breaches copyright or violates any law, please contact openaccess@qub.ac.uk. 


\title{
A Statistical Analysis of Person-to-Vehicle Communications Channels in an Urban Environment at $5.8 \mathrm{GHz}$
}

\author{
Michael G. Doone and Simon L. Cotton \\ The Queen's University of Belfast, UK, http://www.ecit.qub.ac.uk
}

In recent years, the embracement of smart devices carried or worn by people have transformed how society interact with one another. This trend has also been observed in the advancement of vehicular networks. Here, developments in wireless technologies for vehicle-to-vehicle (V2V) and vehicle-to-roadside (V2R) communications are leading to a new generation of vehicular networks. A natural extension of both types of networks will be their eventual wireless integration. Both people and vehicles will undoubtedly form integral parts of future mobile networks of people and things. Central to this will be the person-to-vehicle (P2V) communications channel. As the P2V channel will be subject to different signal propagation characteristics than either type of communication system considered in isolation, it is imperative the characteristics of the wireless channel must first be fully understood. To the best of the author's knowledge, this is a topic which has not yet been addressed in the open literature. In this paper we will present our most recent research on the statistical characterization of the $5.8 \mathrm{GHz}$ person-to-vehicle channel in an urban environment.

The experiments considered a transmitter positioned at different locations on both the body and multiple receivers positioned on the vehicle. The transmitter was alternated between positions on the central chest region, back and the wrist (facing the roadside) of the body, while the receivers placed on the outside roof, the outside rear window and the inside dashboard of the car. This setup allowed nine different person-to-vehicle channels to be analyzed. Measurements were repeated at four different vehicle speeds of $0 \mathrm{mph}$, $10 \mathrm{mph}, 20 \mathrm{mph}$ and $30 \mathrm{mph}$. The environment considered in this study was a business district environment in the Titanic Quarter of Belfast, UK. As shown in Fig. 1, the area consisted of a straight road with office buildings surrounding the immediate vicinity. As an example, Fig. 2 shows the Rice cumulative distribution function (CDF) fitted to the empirical CDF plots for the chest-to-vehicle channels as the vehicle travelled at $30 \mathrm{mph}$. The CDF plot shows the Rice fading model to be an accurate fit at higher signal levels, with decreasing accuracy at lower signal levels. The study shows a dominant signal component existed in the majority of the $\mathrm{P} 2 \mathrm{~V}$ channels considered, with Rice $K$ factor typically much greater than zero. Among the other fading models fitted to the channel data were the Nakagami- $m$ and Weibull distributions, these results will also be presented.

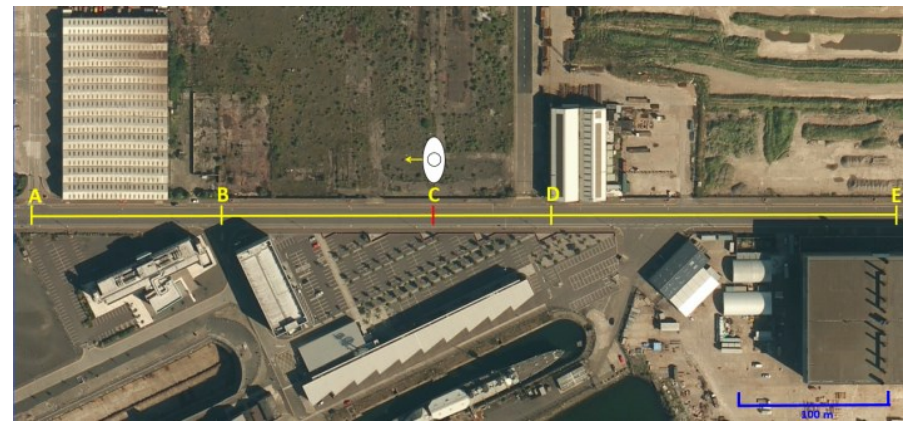

Fig. 1 Satellite view of measurement environment showing vehicle trajectory from point $\mathrm{A}$ to $\mathrm{E}$; with transmitter on a stationary body at point $\mathrm{C}$ as shown. For the duration of the measurements, the test subject was oriented such that they faced directly towards point A.

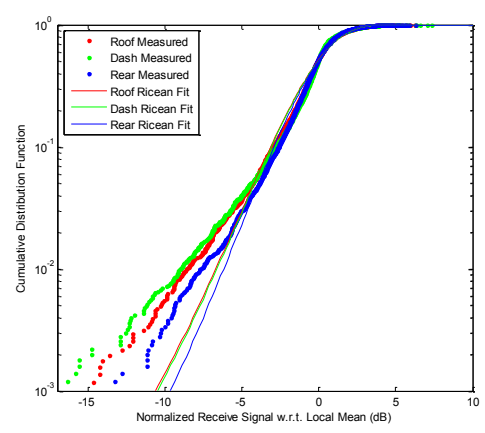

Fig. 2. Empirical and theoretical Rice $\mathrm{CDFs}$ for the chest to vehicle channel while the car travelled at $30 \mathrm{mph}$. 